\title{
Stimulation of Phosphofructokinase from Phycomyces blakesleeanus and Some Other Fungi by Micromolar Concentrations of Fructose 2,6-bisphosphate
}

\author{
By ANDRÉ J. VAN LAERE \\ KULeuven, Laboratory for Plant Biochemistry, Kardinaal Mercierlaan, 92, 3030 Heverlee, \\ Belgium
}

(Received 18 February 1983; revised 3 May 1983)

\begin{abstract}
The phosphofructokinase in crude extracts of Phycomyces blakesleeanus required the presence of ammonium salts, AMP or fructose 2,6-bisphosphate for its activity. The enzyme had slightly sigmoidal kinetics with respect to fructose 6-phosphate as substrate. It was slightly inhibited by high ATP concentrations and by citrate. Fructose 2,6-bisphosphate stimulated the Phycomyces blakesleeanus phosphofructokinase; the $K_{\mathrm{m}}$ for fructose 6-phosphate decreased, the inhibition by ATP was completely relieved and the affinity for the activator ammonia was increased. AMP also stimulated the catalytic activity but there was poor co-operation with fructose 2,6-bisphosphate. Preliminary experiments showed that fructose 2,6-bisphosphate also stimulated the phosphofructokinase from Mucor rouxii, Neurospora tetrasperma and Agaricus bisporus.
\end{abstract}

\section{INTRODUCTION}

Dormant sporangiospores of Phycomyces blakesleeanus can be induced to germinate by several treatments including heating at $50{ }^{\circ} \mathrm{C}$ for a few minutes (Robbins et al., 1942) or by treatment with acetate (Borchert, 1962). The most prominent biochemical feature of germinating spores is a large increase in glycolytic activity. This is manifested by an increased oxygen uptake (Van Laere et al., 1980) and the production of large amounts of glycerol (Furch et al., 1976), pyruvate (Rudolph et al., 1966; Van Laere et al., 1982) and lactate (Furch, 1972) during early germination. An increased glycolytic activity was also found after activation of Neurospora ascospores (Eilers et al., 1970).

PFK is believed to regulate the glycolytic flow in a variety of organisms and special attention has recently been focused on the effects of Fru-2,6- $\mathrm{P}_{2}$ on this enzyme (Van Schaftingen et al., 1980). Fru-2,6- $P_{2}$, in less than micromolar concentrations, activates PFK from several mammalian sources (Hers \& Van Schaftingen, 1982), Saccharomyces cerevisiae and two Rhodotorula species (Bartrons et al., 1982) as well as the PFK from Ricinus communis plastids (Miernyk \& Dennis, 1982). Fru-2,6- $\mathrm{P}_{2}$ has no effect on bacterial PFKs (H. G. Hers, personal communication). In plants it stimulates inorganic pyrophosphate: D-fructose-6-phosphate 1phosphotransferase (Sabularse \& Anderson, 1981); this enzyme may contribute significantly to glycolytic flow in green tissues of several plants (Carnal \& Black, 1983).

This paper describes an investigation of the effects of Fru-2,6- $\mathrm{P}_{2}$ on the PFK of Phycomyces blakesleeanus as part of an attempt to gain a better understanding of the regulation of glycolysis in Phycomyces spores.

\section{METHODS}

Organisms. Experiments were done with sporangiospores of Phycomyces blakesleeanus Burgeff (Strain K) and Mucor rouxii (CBS 416.77), with ascospores of Neurospora tetrasperma (CBS 377.74) or commercially available Agaricus bisporus caps.

Abbreviations: Fru-2,6,- $\mathrm{P}_{2}$, fructose 2,6-bisphosphate; PFK, ATP :D-fructose-6-phosphate 1-phosphotransferase (EC 2.7.1.11). 
Preparation of extracts. The spores (50 mg dry wt) or caps were homogenized (Van Laere et al., 1976) in 1.5 ml $50 \mathrm{mM}-\mathrm{HEPES} / \mathrm{KOH}, \mathrm{pH} 7 \cdot 5$, containing $5 \mathrm{~mm}$-mercaptoethanol. After homogenization, the extract was diluted to $2.5 \mathrm{ml}$ and centrifuged for $15 \mathrm{~min}$ at $58000 \mathrm{~g}\left(3^{\circ} \mathrm{C}\right)$. The clear supernatant was used immediately to assay enzyme activity.

Assay of PFK activity. Enzyme activity was monitored spectrophotometrically at $25^{\circ} \mathrm{C}$ by measuring the disappearance of NADH. The reaction mixture contained, except when stated otherwise, $25 \mathrm{mM}-\mathrm{HEPES}, 12.5 \mathrm{mM}-$ $\mathrm{KOH}, 2.5 \mathrm{~mm}$-mercaptoethanol, $12.5 \mathrm{~mm}-\left(\mathrm{NH}_{4}\right)_{2} \mathrm{SO}_{4}, 5 \mathrm{~mm}-\mathrm{MgSO}_{4}, 1 \mathrm{mM}$-ATP, 2 mM-fructose 6-phosphate, $0.2 \mathrm{mM}$-NADH, 0.18 units aldolase, 0.6 units glycerolphosphate dehydrogenase and 2 units triosephosphate isomerase (all from Boehringer). The final $\mathrm{pH}$ was $7 \cdot 5$. Since the extract contained large amounts of phosphoglucose-isomerase activity, the fructose 6-phosphate was added as an equilibrium mixture with glucose 6-phosphate (ratio 1:3). Control samples were measured without fructose 6-phos̀phate; these yielded low values which were subtracted from the reaction velocities. Tests in the absence of ammonium salts were done with coupling enzymes which had been desalted by passing through Sephadex G-10 equilibrated with extraction buffer. It was ascertained that under all conditions assayed the reaction velocity was not limited by the activity of the coupling enzymes. Although a crude extract was used, the 2500 -fold dilution used during the assay should have diluted the concentration of endogenous components that might affect the assay to negligible levels. Some variation in specific activity occurred among different extracts and so the results presented in each figure were obtained with the same extract. All experiments were repeated and gave consistent results.

Fru-2,6-P $\mathrm{P}_{2}$ was a gift from Professor H. G. Hers.

\section{RESULTS AND DISCUSSION}

Ammonium ions stimulated PFK activity considerably (e.g. Fig. 3), so most experiments were done in the presence or absence of $12.5 \mathrm{mM}-\left(\mathrm{NH}_{4}\right)_{2} \mathrm{SO}_{4}$. Phycomyces blakesleeanus PFK has a $\mathrm{pH}$ optimum between $\mathrm{pH} 7.5$ and 8.5 in HEPES buffer. Activity dropped sharply on the acid side and was only some $10 \%$ of its maximum at $\mathrm{pH}$. This $\mathrm{pH}$ optimum differs markedly from that reported for PFK from yeast cells of the related fungus Mucor rouxii (6.4 in phosphate buffer; Paveto \& Passeron, 1977). Although the use of phosphate buffer could affect the pH optimum observed (Banuelos et al., 1977), the $\mathrm{pH}$ optimum of PFK from P. blakesleeanus spores was not markedly shifted by using phosphate instead of HEPES buffer. The $\mathrm{pH}$ activity curve was not shifted in the presence of ammonium sulphate. Since near optimal activity was obtained at $\mathrm{pH} 7.5$ and since this $\mathrm{pH}$ is likely to reflect the physiological $\mathrm{pH}$, all experiments were done at $\mathrm{pH} 7 \cdot 5$.

In the absence of ammonium ions and Fru-2,6- $\mathrm{P}_{2}$ hardly any PFK activity could be detected in the spore extracts. Under these conditions $5 \mathrm{mM}$-AMP greatly stimulated PFK activity, mainly by a fivefold increase in $V_{\max }$. The dependence on fructose 6-phosphate concentration was slightly sigmoidal (Hill coefficient, 1-7). Fru-2,6- $\mathrm{P}_{2}$ was found to be a much more potent stimulator than AMP. Its presence increased $V_{\max } 23$-fold and lowered the $K_{\mathrm{m}}$ for fructose 6phosphate (from $0.25 \mathrm{~mm}$ with AMP to $0.1 \mathrm{mM}$ with Fru-2,6- $\mathrm{P}_{2}$ ), resulting in less hyperbolic kinetics (Fig. 1a). Addition of AMP had no further stimulatory effect in the presence of $1 \mu \mathrm{M}-$ Fru-2,6-P .

In the presence of $12.5 \mathrm{mM}-\left(\mathrm{NH}_{4}\right)_{2} \mathrm{SO}_{4}$ considerable PFK activity was found (more than tenfold stimulation) without addition of any activator (Fig. 1 b). The dependence on fructose 6phosphate concentration remained clearly sigmoidal (Hill coefficient, 1.7). Addition of AMP (5 mM) or Fru-2,6- $\mathrm{P}_{2}(1 \mu \mathrm{M})$ increased $V_{\max }$ (about twofold) and decreased the $K_{\mathrm{m}}$ (from $0.5 \mathrm{mM}$ to $0.27 \mathrm{mM}$ with AMP and to $0 \cdot 15 \mathrm{mM}$ with Fru-2,6- $\mathrm{P}_{2}$ ).

The effect of ATP concentrations on PFK activity is shown in Fig. 1. In the absence of ammonium ions (but in the presence of AMP to obtain significant activity) an ATP concentration of $\mathbf{0 . 2} \mathrm{mM}$ was optimal, although higher concentrations were only slightly inhibitory (Fig. $1 c$ ). In the presence of $\mathrm{NH}_{4}^{+}$ions (Fig. $1 d$ ) a broader optimum was obtained: about $0.5 \mathrm{mM}-$ ATP in the absence and about $2 \mathrm{mM}$ in the presence of AMP. The presence of $1 \mu \mathrm{M}-\mathrm{Fru}-2,6-\mathrm{P}_{2}$, however, removed all inhibitory effects of ATP and yielded a nearly hyperbolic concentration dependence.

AMP stimulated the enzyme not only by a decrease in the $K_{\mathrm{m}}$ for fructose 6-phosphate but also by an increase in the $V_{\max }$. Depending on the fructose 6-phosphate concentration, optimum 


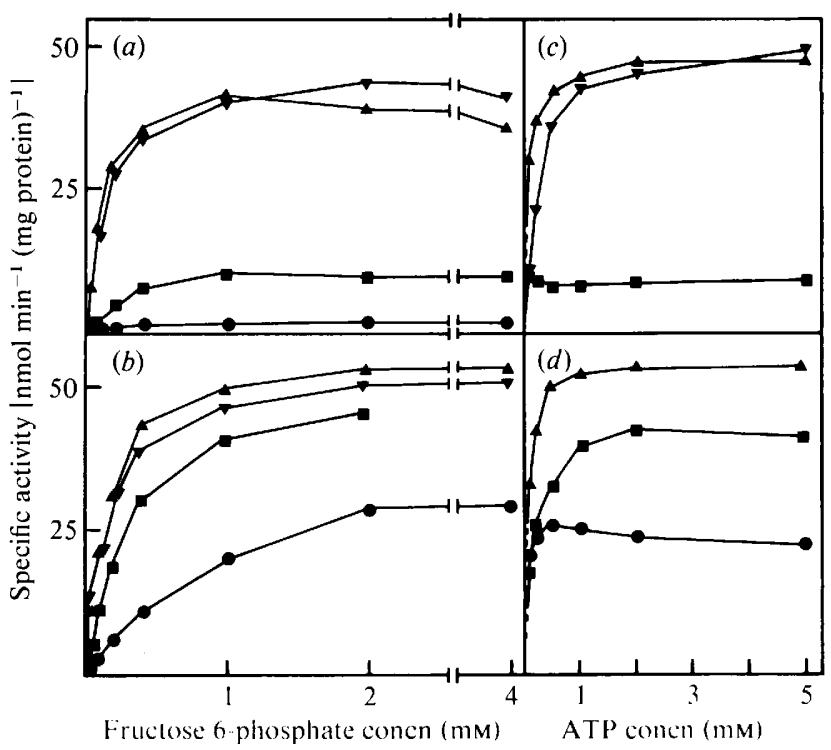

Fig. 1. Effect of fructose 6-phosphate concentration on PFK activity in the absence $(a)$ or presence $(b)$ of $12.5 \mathrm{mM}^{-}\left(\mathrm{NH}_{4}\right)_{2} \mathrm{SO}_{4}$ (ATP, $\left.1 \mathrm{~mm} ; \mathrm{Mg}^{2+}, 5 \mathrm{mM}\right)$ and the effect of ATP concentration on PFK activity in the absence $(c)$ or presence $(d)$ of $12.5 \mathrm{mM}-\left(\mathrm{NH}_{4}\right)_{2} \mathrm{SO}_{4}$ (fructose 6-phosphate $2 \mathrm{mM} ; \mathrm{Mg}^{2+}$,

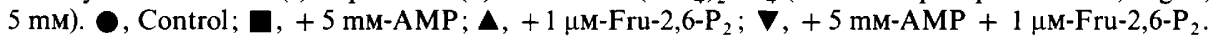

stimulation by AMP was obtained at 2 to $5 \mathrm{mM}$. However, AMP had no effect in the simultaneous presence of $1 \mu \mathrm{M}-\mathrm{Fru}-2,6-\mathrm{P}_{2}$.

Citrate, an inhibitor of several PFKs (Bloxham \& Lardy, 1973), was only slightly inhibitory $(30 \%$ inhibition at $10 \mathrm{~mm})$. Fru-2,6- $\mathrm{P}_{2}$ relieved this inhibition.

The most clearcut stimulation of PFK by Fru-2,6- $\mathrm{P}_{2}$ was obtained in the absence of ammonium salts (Fig. 2). In this case activity was nearly dependent on the presence of Fru-2,6$\mathbf{P}_{2}$ (or AMP). In the presence of AMP the stimulation by Fru-2,6- $P_{2}$ was less important. AMP slightly increased the affinity of the enzyme for Fru-2,6-P $\mathrm{P}_{2}$. Similar though less pronounced stimulations were obtained in the presence of ammonium ions (results not shown). As in liver (Van Schaftingen et al., 1981) and yeast (Bartrons et al., 1982) Fru-2,6- $\mathrm{P}_{2}$ decreased the $K_{\mathrm{m}}$ for fructose 6-phosphate. As in yeast, but unlike liver, $V_{\max }$ was also affected. Poor synergism of the Fru-2,6- $\mathrm{P}_{2}$ response with AMP was found compared with the yeast and liver enzymes; the inhibition by high ATP concentration was completely removed by Fru-2,6- $\mathrm{P}_{2}$ with the Phycomyces enzyme, resulting in hyperbolic kinetics towards ATP concentration.

Enzyme activity was also dependent on the presence of $\mathbf{M g}^{2+}$ salts. Optimal activity with $1 \mathrm{mM}-\mathrm{ATP}$ was obtained at $1 \mathrm{mM}-\mathrm{Mg}^{2+}$. Higher concentrations inhibited to a variable degree depending on the conditions of the assay.

The activity of Phycomyces PFK was stimulated by the presence of ammonium salts (Fig. 3). $\mathrm{Na}_{2} \mathrm{SO}_{4}$ up to $20 \mathrm{mM}$ had little effect on PFK activity. In the absence of other effectors, saturation was only obtained at ammonium concentrations above $40 \mathrm{mM}$. In the presence of Fru-2,6- $\mathrm{P}_{2}$ the dependence on ammonium ions was not so absolute but a substantial stimulation was still obtained. Moreover, AMP, and especially Fru-2,6- $\mathrm{P}_{2}$, increased the sensitivity of ammonium salts, since near maximal stimulation was obtained at 10 to $20 \mathrm{~mm}$ (with $1 \mathrm{~mm}$ AMP) or 2 to $4 \mathrm{mM}$ (with $1 \mu \mathrm{M}-\mathrm{Fru}-2,6-\mathrm{P}_{2}$ ). The PFK from Dictyostelium discoideum was also dependent on the presence of ammonium ions (Baumann \& Wright, 1968). Several other PFKs, especially the yeast enzyme, are activated by ammonium (Mavis \& Stellwagen, 1970). In yeast, however, the effect of ammonium can be mimicked by $\mathrm{K}^{+}$, but this is not true for the Phycomyces enzyme and only partly for the Dictyostelium enzyme (Baumann \& Wright, 1968). All our 


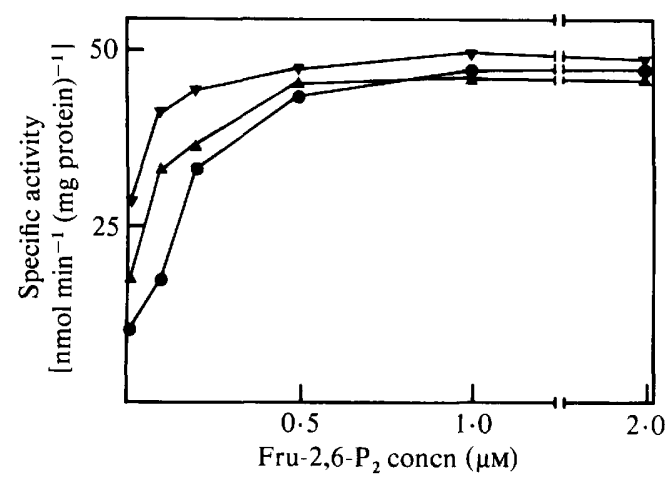

Fig. 2

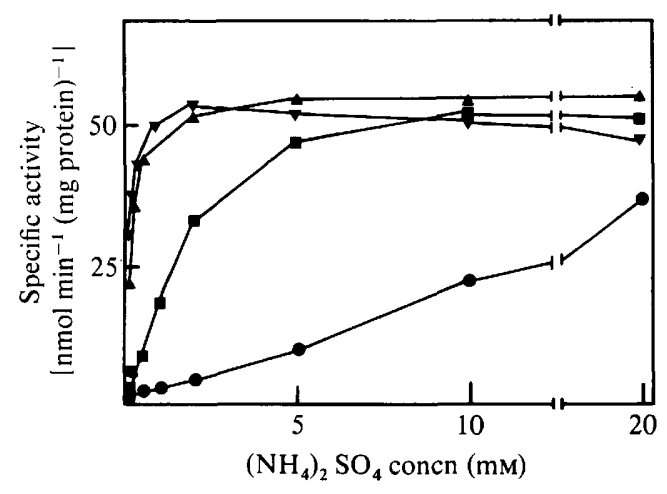

Fig. 3

Fig. 2. Effect of Fru-2,6-P on PFK (ATP, $1 \mathrm{~mm}$; $\mathrm{Mg}^{2+}, 5 \mathrm{mM}$; fructose 6-phosphate, $1 \mathrm{mM}$ ). Control; $\boldsymbol{\Delta},+0 \cdot 2 \mathrm{mM}-\mathrm{AMP} ; \boldsymbol{\nabla},+1 \mathrm{mM}-\mathrm{AMP}$.

Fig. 3. Effect of $\left(\mathrm{NH}_{4}\right)_{2} \mathrm{SO}_{4}$ concentration on PFK activity (ATP, $1 \mathrm{~mm}$; fructose 6-phosphate, $2 \mathrm{~mm}$; $\left.\mathrm{Mg}^{2+}, 5 \mathrm{mM}\right)$. Control; $\boldsymbol{\square},+1 \mathrm{mM}-\mathrm{AMP} ; \boldsymbol{\Lambda},+1 \mu \mathrm{M}-$ Fru-2,6-P $; \boldsymbol{\nabla},+1 \mathrm{mM}-\mathrm{AMP}+1 \mu \mathrm{M}-$ Fru$2,6-\mathrm{P}_{2}$

experiments were done in $25 \mathrm{mM}-\mathrm{K}^{+} /$HEPES with a $\mathrm{K}^{+}$concentration above $10 \mathrm{mM}$. Moreover, addition of supplementary $\mathrm{K}^{+}$did not stimulate enzyme activity.

Preliminary experiments indicated that the PFKs from Mucor rouxii (Zygomycetes), Neurospora tetrasperma (Ascomycetes) and Agaricus bisporus (Basidiomycetes) were activated by Fru-2,6- $\mathrm{P}_{2}$ in micromolar concentrations. The PFK from Mucor was most sensitive, whereas stimulation in Agaricus was less pronounced and occurred at slightly higher concentrations.

\section{Conclusion}

The in vivo activity of Phycomyces blakesleeanus PFK is probably regulated by a combination of Fru-2,6- $\mathrm{P}_{2}$, ammonium ions and the concentration of fructose 6-phosphate. Citrate and ATP are poor effectors, certainly in the presence of Fru-2,6-P $\mathrm{P}_{2}$. Regulation by AMP is probably not involved in vivo since high concentrations are needed and the AMP effect is overshadowed by the effector Fru-2,6-P $\mathbf{P}_{2}$. The increased glycolytic activity of Phycomyces spores during early germination could be due to an increased availability of substrate, to increases in the concentration of Fru-2,6- $\mathrm{P}_{2}$ or ammonia. Although preliminary experiments confirm the presence of Fru-2,6- $\mathrm{P}_{2}$ in Phycomyces spores (E. Van Schaftingen \& A. Van Laere, unpublished), its role in the germination of Phycomyces spores remains to be investigated. The effect of Fru-2,6- $\mathbf{P}_{2}$ in extremely low concentrations on the PFK of both yeast (Bartrons et al., 1982) and mycelial forms of fungi from different classes might indicate an important role of the compound in fungal metabolism.

The author is a research associate at the National Fund for Scientific Research (Belgium) and is grateful to Professor H. G. Hers and Dr E. Van Schaftingen for the generous gift of Fru-2,6-P and for critical discussion.

\section{REFERENCES}

Banuelos, M., Gancedo, C. \& Gancedo, J. M. (1977). Activation by phosphate of yeast phosphofructokinase. Journal of Biological Chemistry 252, 6394-6398.

Bartrons, R., Van Schaftingen, E., VisSers, S. \& Hers, H. G. (1982). The stimulation of yeast phosphofructokinase by fructose-2,6-bisphosphate. FEBS Letters 143, 137-140.
BaumanN, P. \& Wright, B. E. (1968). The phosphofructokinase of Dictyostelium discoideum. Biochemistry 7, 3653-3661.

BloXhaM, D., \& LaRdY, H. (1973). Phosphofructokinase. In The Enzymes, vol. 8a, pp. 240-278. Edited by P. Boyer. New York: Academic Press.

BORCHERT, R. (1962). Über die Azetat-Aktivierung der Sporangiosporen von Phycomyces blakesleeanus. Beiträge zur Biologie der Pflanzen 38, 31-61. 
Carnal, N. W. \& BlaCK, C. C. (1983). Phosphofructokinase activities in photosynthetic organisms. Plant Physiology 71, 150-155.

Eilers, F. I., IkUma, H. \& Sussman, A. S. (1970). Changes in metabolic intermediates during activation of Neurospora ascospores. Canadian Journal of Microbiology 16, 1351-1356.

FURCH, B. (1972). Zur Wärmeaktivierung der Sporen von Phycomyces blakesleeanus. Das Auftreten von Gärungen unter aeroben Bedingungen. Protoplasma 75, 371-379.

FURCH, B., POLTZ, J. \& RUdOLPH, H. (1976). Lipids of spores from Phycomyces in relation to heat induced germination. Microbios Letters 8, 71-80.

Hers, H. G. \& Van Schaftingen, E. (1982). Fructose2,6-bisphosphate two years after its discovery. Biochemical Journal 206, 1-12.

Mavis, R. D. \& Stellwagen, E. (1970). The role of cations in yeast phosphofructokinase catalysis. Journal of Biological Chemistry 245, 674-680.

MIERNYK, J. \& DENNIS, D. (1982). Activation of the plastid isozyme of phosphofructokinase from developing endosperm of Ricinus communis by fructose2,6-bisphosphate. Biochemical and Biophysical Research Communications 105, 793-798.

Paveto, C. \& Passeron, S. (1977). Some kinetic properties of Mucor rouxii phosphofructokinase. Archives of Biochemistry and Biophysics 178, 1-7.

Robbins, W. J., KavanaGh, V. W. \& KavanaGh, F. (1942). Growth substances and dormancy of spores of Phycomyces. Botanical Gazette 104, 224-242.

RUDOLPH, H., KRÜGER, C. \& SIEBELDS, J. (1966). Über Änderungen des Brenztraubensäure- und ATPGehaltes wärmeaktivierter Sporen von Phycomyces blakesleeanus. Zeitschrift für Pflanzenphysiologie $\mathbf{5 5}$, 415-428.

SABularse, D. C. \& ANDERson, R. L. (1981). Dfructose-2,6-bisphosphate: a naturally occurring activator of inorganic pyrophosphate: D-fructose-6phosphate 1-phosphotransferase in plants. Biochemical and Biophysical Research Communications 103, 848-855.

Van Laere, A. J., Carlier, A. R. \& Van Assche, J. A. (1976). Effect of 5-fluorouracil and cycloheximide on early development of Phycomyces blakesleeanus spores and the activity of $N$-acetyl-glucosamine synthesizing enzymes. Archives of Microbiology 108, 113-116.

VAN Laere, A. J., Van Assche, J. A. \& Carlier, A. R. (1980). Reversible and irreversible activation of Phycomyces blakesleeanus spores. Experimental $M y$ cology 4, 96-104.

VAN LAERe, A. J., VAN DEN Bosch, R. \& Carlier, A. R. (1982). Pyruvate metabolism by mitochondria from dormant and activated Phycomyces blakesleeanus spores. Journal of General Microbiology 128, 1537-1545.

VAN Schaftingen, E., Hue, L. \& Hers, H. G. (1980). Fructose-2,6-bisphosphate, the probable structure of the glucose and glucagon-sensitive stimulator of phosphofructokinase. Biochemical Journal 192, 897901.

Van Schaftingen, E., Jett, M., Hue, L. \& Hers, H. G. (1981). Control of liver 6-phosphofructokinase by fructose-2,6-bisphosphate and other effectors. Proceedings of the National Academy of Sciences of the United States of America 78, 4383-4386. 